\title{
Chinese Sports Management System Reform and Development Trend
}

\author{
Jingliang Zhang \\ Shandong Sport University \\ Jinan,Shandong,250102 China
}

\begin{abstract}
Review and summarize China's basic situation of sports management reform research. The results showed that Chinese sports management reform are internal and external interactions results. The ultimate goal of Chinese Sport Management System is built in line with China's actual conditions, benign running sports management system and operation mode. Currently Chinese S port Management System presents distinctive transitional characteristics. Chinese sports system reform has achieved some results, but there are certain problems and shortcomings.
\end{abstract}

Keywords- Sports management system reform, Commentary

\section{INTRODUCTION}

From the early days to the present, China's political, economic, cultural, educational, great changes have taken place, the same changes in sports management system is obvious. From the collective to the type of the nationwide system of combining decentralized and centralized system, from nationalization to socialization, China's sports management systemhas been continually reform.

\section{HIST ORICAL DEVELOPMENT OF CHINESE SPORTS MANAGEMENT SYSTEM}

Beginning in 1949, a new sports career also began construction work. In 1952 the Central Committee by the Party Central Committee and the Central People's Government commissioned the formation of the All-China Sports Federation. It is in charge of the Central Committee to the All-China Sports Federation for the specific operation to the Ministry of Education, the ACFTU and other departmental systems for the parties to cooperate in sports management. July 1952, because of the wrong policies of the International Olympic Committee, the Chinese failed to appear on the 15th Olympic Games, only rushed at the closing ceremony. The new China was strong political stimuli, and made with high-level competitive sports to safeguard national dignity and national unity choice. In November, the central government decided to set up the Central People's Sports Committee, to take over the sports associations and sports clubs defense, renamed the Sports Committee People's Republic of China in 1954. From 1953 to 1956 , set up a national track and field, table tennis and other projects, 1956 established a nationwide youth amateur sports schools, government organizations, sport management system gradually established. After 1956, China completed the socialist transformation of the three planned economic system and gradually strengthened. Reform of the economic system also affected the sport. In 1957, the All-China Sports Federation of China Sports Commission to modify the Articles of Association, the general task of modifying the amateur sports leadership People's Republic of China, the specific tasks only promotional contests mass work and organization. But the impact of China's political and economic system, the Chinese total body exercise limited authority does not only exist in name, Sports Authority replaces these social ass ociations. Cultural Revolution Sports Commission was once military control, but this is not beating the nationwide system, restore the body appointed in 1971, is highly concentrated right again, and create the conditions for its development. This period of development, the National Sports Commission actually swept all aspects of the national sports bear most of the economic burden, the use of highly centralized type operating mechanism, an exclusive sports leadership and management model, the formation of more than forty Chinese sports management Since the reform and opening years of the establishment of the nationwide economic development as the central public ownership as the mainstay and co-existence of various economic components of a market economy in order to further achieve the goal of a sports power in 1980, the State Council approved the National Sports Commission on accelerating the movement to improve the technical level reports; in 1983 the State Council issued a notice requiring the movement to achieve world-class technical level, becoming one of sports power; 1984 the CPC Central Committee issued a further notice of sports development; 1985, the National Sports Development Strategy Seminar think realization sports power important goal is the implementation of the Olympic strategy; 1986 National Sports Commission announced the National Sports Commission decision on sports reform (draft), adhere to national guidelines proposed a game of chess, to further clarify the implementation of the Olympic strategy. The software has been installed nationwide system in place to begin the rapid development of power play. 


\section{CHARACTERISTICS AND CAUSES OF CHINESE SPORTS MANAGEMENT SYSTEM ANALYSIS}

Causes of centralized management type of sports management system from top to bottom of the main features are the following:

Choose closely with the planned economic system. A country's political and economic system, the management system for the sport has a decisive influence, China's planned economy, sport and culture industry is regarded as a national public utilities for centralized management, with this adaptation, sport management system usually belong to the government managed. With the national level of economic development are closely related. Sport as a cultural and entertainment industry, the low level of economic development of the country, the case has not been resolved subsistence people, society can not also unable to assume responsibility for the support and development of sports. When new China was founded, the economic base is extremely weak, can only be taken in order to develop national sports centralized management system. The same degree of development of China's sports is closely related. Westernization Movement opened Western Gymnastics Academy appear until the founding of New China, Western sports gradually occupy the dominant position of sports in our country, but its development is very slow, circular only on a lower level since. After the founding of New China to boost national spirit and let the world know China as soon as possible, choose centralized management and rapid development of China's sports system in sports is also reasonable. With the height of the lack of spiritual resources is closely related to sports. Confucianism is the orthodoxy of the ruling class, Confucianism advocates heavy paper and light weapons, leading to the physical characteristics of the sport for the long-term lack of resources and support the spirit of the slow development. After the founding of New China, relying on the community in a highly scarce resource situation to develop the spirit of sport is very tough, it can only take the government to centrally manage sport system. With national trends in health-re lated development, since the Sino-Japanese War, the Opium War, China is facing life and death crisis, advocates from CaiE militarism, Kang and Liang of the May Fourth Movement of Democratic Reform, science, patriotism, until the new China has been established, the family's control of the human body gradually Let located in the state, national trend that increasingly dominate the body, the body gradually become the survival of the country out of crisis, defending the homeland, the construction of the motherland, tools and instruments for national service.

\section{FACTORS THAT PROMOTE THE DEVELOPMENT OF CHINESE SPORTS MANAGEMENT SYSTEM}

A country's political and economic system, the degree sports management system has a decisive influence, and with the country's political and economic systems coincide, is a measure of the main criteria for Sport Management System reasonable or not. After China adopted socialism as "the three reform" in 1956 to 1978 , before the reform and opening, China is a socialist country with a planned economy, the state administrative means management of sports, bear most of the obligations, mastered almost All powers belong to the government at this time managed. After the implementation of China's socialist market economy, the new sports management system along with the emergence of a typical start to a nationwide system of government, society bound institutional change.

\section{CHINESE SPORTS PERFORMANCE MANAGEMENT SYSTEM}

Most domestic scholars on this issue mostly adopted a more objective attitude. As for the perception of competitive sports system is generally believed that, since the 20th century, after the leaves, due to various internal and external factors, China has gradually formed its own professional sports system (nationwide system), and is still competitive sport in China plays an important role. Nationwide system features and advantages of our country, our country is not yet developed in the economic situation, has made brilliant achievements one after another foundation and protection. Although in our planned economy to a market economy in the process of integration, nationwide system of competitive sports in the operation inevitably encountered many new problems, which need to be resolved through reform, adjustment and improvement, and has been in innovation and development. Undoubtedly, the nationwide system and the key to success is the holy grail of high-speed development of competitive sports. It makes the sport in China and strong countries and weak social model of development has made brilliant achievements. Some scholars have thus made: As a result of the nationwide system of competitive sports in our country is not yet a strong national situation, quickly established a leading position in Asia and the world, which for the purposes of a weak base, a large population of developing countries, there is no precedents. China's sports scholar Profes s or Hao Qin should be made

History, objective, dialectical view of Chinese professional sports system, Emergence of contemporary Chinese professional sports system has its complicated historical background and reasons. First, China is a big country with a history of complex mental attitude is the basis of Chinese society of professional athletics generated. Second, the relationship between sports and politics become the basic motivation Chinese professional athletics. Third, the planned economy is the economic foundation of China's professional athletics system. Fourth, the organizational model of wartime combat team formed Chinese contemporary professional athletics have had a profound impact on the system. Fifth, the whole

Games will be the highest form of professional athletics system. This is the objectivity and reality in China's professional athletics system. Must see, 80 years later, in the Chinese sports management system model, China has adopted a strategic priority to the development of competitive sports, but it is making the tilt of the development of competitive sports practiced, at the expense of the development of mass sports for the price. Visible, although China has played a sports management system performance under specific historical conditions, but this 
performance is local, or even a pathological development. While some scholars of the current Chinese sports

Certain transitional management system appear negative factors expressed regret, but it certainly is the concept of change brought about sports reform, expansion of the scope of management, innovation management tools remarkable achievements. As for the lead in implementing the reform of professional football, the Chinese football reform so that the overall level of Chinese football has improved greatly enhanced with Asian teams and the world's ability to compete. Meanwhile, the Chinese football reform also provides a valuable experience for other sports, etc. reform. Obviously, the results certainly should be, but more should see less and challenges in front of both trends, "seek the best path Chinese sports management reform, to achieve sustainable development of China's sports is still a pressing contemporary issues .

\section{DEVELOPMENT TREND OF CHINA'S SPORT S SYSTEM}

Macro-and micro-functional sports management functions will be fully strengthened. In the management authority, the state no longer do everything matters, the powers to do sports community to exercise, give full play to the basic units and individual self-management, selfdevelopment initiative, the state administrative organs only macroeconomic decisions, coordination, supervision, The combination of macro and micro management more closely and better, so that the macro-and micro-functional sports management functions are fully strengthened. Government management and social management based management system will coexist for some time. Because unbalanced Chinese economy, cultural development, government management and social management system managed coexist, but also to maintain a considerable period of time. In some economic backwardness, cultural enclosed areas (such as the western region), the cause of sports-loaded, because of the social economy is weak enough to as sume responsibility for the support and management of sport, government managed system had to be retained, and its responsibilities should be strengthen; while in a developed economy, sports market is relatively mature areas, sports socialization and high degree of industrialization, industrial nature of the prominent, gradually formed social managed system. Government and community management model is combined with the basic orientation of Sports Management System. Government in accordance with the Constitution and relevant laws and regulations in the planning, guidance, organization, supervision and the development of sports development policy has played a leading role, and dynamically adjust the ratio of the tube and do according to socio-economic development, to ensure the achievement of national goals and interests of the mass sports. That is the government's sports admin istration department should strive to adjust their relationship with sports as sociations and other sports organizations to form a legal relationship and agreement, rather than direct management relations; hand the government actively to sports associations, quasiadmin is trative agencies, the private sector and other sports organizations decentralized allocation of resources based on social sports demand, the introduction of market mechanism. Through sports-related legislation and policies, social sports clubs, sports associations will gradually complete the process of physical; personnel exchange system will become more scientific and rational, while introducing market competition mechanism, in accordance with market demand and safeguard policies and regulations to carry out the distribution of benefits. The most basic principle of the market economy is the market play a fundamental role in resource allocation. Based on the theory of the market economy, there is a whole community of sports in the sports industry quasi-private goods, sports goods and quasi-public goods have a mix of both private three cases of public goods. In the public part of the sports industry should be managed by the government, investment and development in order to meet the demand for sport. Private goods are part of the sports industry should be by the power companies, clubs and associations and civil society organizations to carry out the management and development. In the middle part of the intersection is coordinated with both the government and the social forces for development.

In short, the causes of top-down management system with choice of sports planned economy, the degree of development of the national economy and sports, as well as the height of the lack of national development trend of physical resources is closely related to the spirit of sport. In the future, macro-and micro-functions of sports management functions will be fully strengthened, government management and social management based management system will coexist for some time, the govemment and the community management model is combined with the basic orientation of Sports Management System.

\section{REFERENCES}

[1] Wang Lijuan, Zhoubo. Chinese Sport Management System two decades [J]. SPORT S SCIENCE,2002,06:4 -6.

[2] Xiaolin Peng. Chinese Sports Management System Reform Research Review. [J]. XI'AN INST ITUTE OF PHYSICAL,2005,01:23-26.

[3] Liu Dongfeng.Chinese sports system reform path selection [J]. Chengdu Institute of Physical Education,2005,02:20-23.

[4] Sun Keyi, Qin Chun Lin. Discussion Sports Management System and Chinese Sport Management System [J]. Beijing Sport University, 1995,01:6-13.

[5] Song Jixin. On the Reform and Development of China's sports management system structure [J]. Sports science, 1998,01:16-19.

[6] Han Bing. After the 2008 Olympics strategic choice China Sports Management System [J]. SPORTS ADULT, 2006,02:33-34.

[7] Lirong Zhi, Tang Wenbing research trends in sports management system of the 2008 Olympic Games [J]. Chengdu Inst it ute of Physical Education,2007,06:7-10 